Final Report

Demonstration of Micro-Combined Heat and Power for Light Commercial Applications

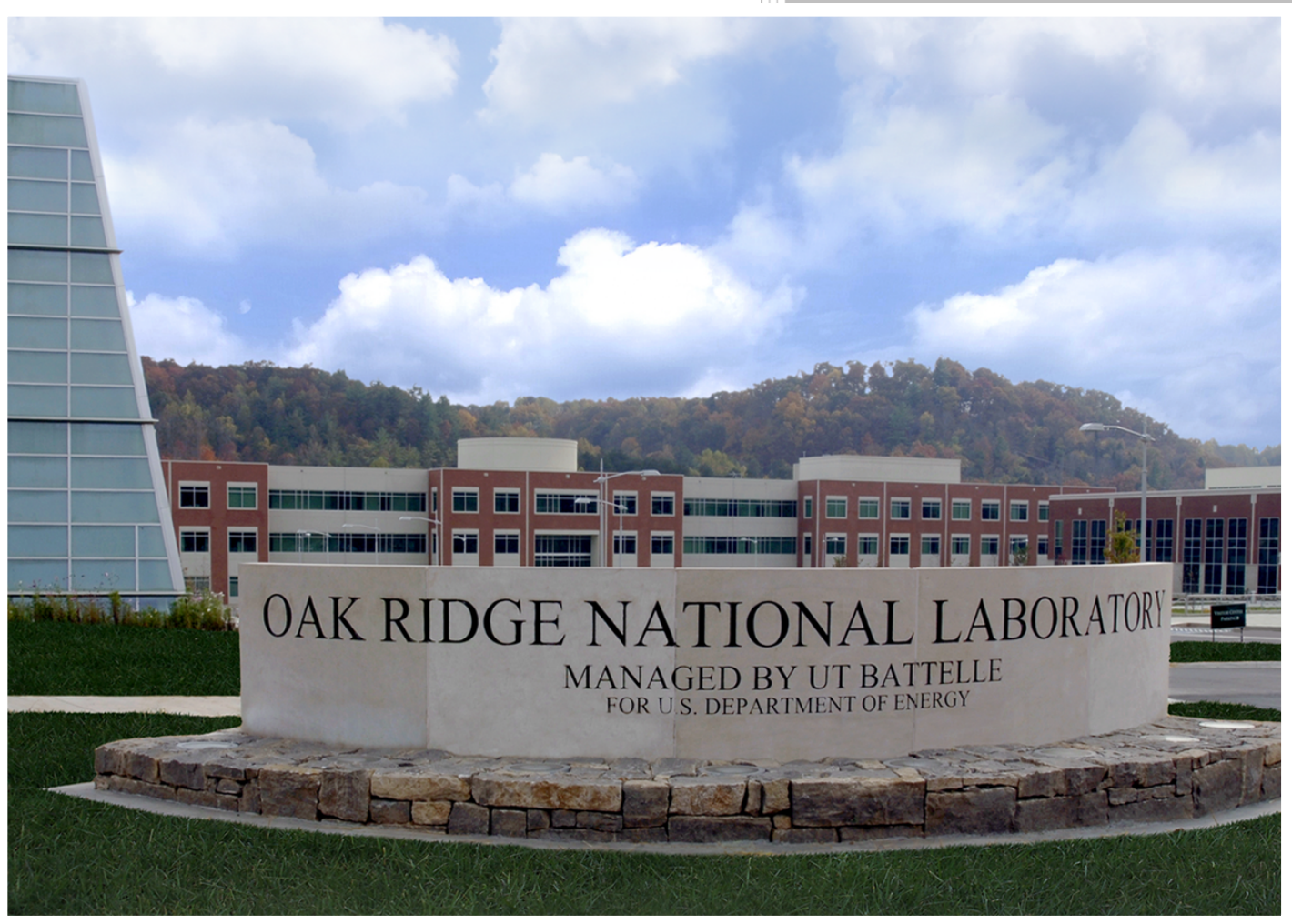

Piljae Im Heather Buckberry Anthony Gehl Kris Jorgensen 



\section{DOCUMENT AVAILABILITY}

Reports produced after January 1, 1996, are generally available free via the U.S. Department of Energy (DOE) Information Bridge.

Web site http://www.osti.gov/bridge

Reports produced before January 1, 1996, may be purchased by members of the public from the following source.

National Technical Information Service

5285 Port Royal Road

Springfield, VA 22161

Telephone 703-605-6000 (1-800-553-6847)

TDD 703-487-4639

Fax 703-605-6900

E-mail info@ntis.gov

Web site http://www.ntis.gov/support/ordernowabout.htm

Reports are available to DOE employees, DOE contractors, Energy Technology Data Exchange (ETDE) representatives, and International Nuclear Information System (INIS) representatives from the following source.

Office of Scientific and Technical Information

P.O. Box 62

Oak Ridge, TN 37831

Telephone 865-576-8401

Fax 865-576-5728

E-mail reports@osti.gov

Web site http://www.osti.gov/contact.html

This report was prepared as an account of work sponsored by an agency of the United States Government. Neither the United States Government nor any agency thereof, nor any of their employees, makes any warranty, express or implied, or assumes any legal liability or responsibility for the accuracy, completeness, or usefulness of any information, apparatus, product, or process disclosed, or represents that its use would not infringe privately owned rights. Reference herein to any specific commercial product, process, or service by trade name, trademark, manufacturer, or otherwise, does not necessarily constitute or imply its endorsement, recommendation, or favoring by the United States Government or any agency thereof. The views and opinions of authors expressed herein do not necessarily state or reflect those of the United States Government or any agency thereof. 
Energy and Transportation Science Division

\title{
Demonstration of Micro-Combined Heat and Power for Light Commercial Applications
}

\author{
Piljae Im \\ Heather Buckberry \\ Anthony Gehl \\ Kris Jorgensen
}

Date Published: September 30, 2019

Prepared by

OAK RIDGE NATIONAL LABORATORY

Oak Ridge, Tennessee 37831-6283

managed by

UT-BATTELLE, LLC

for the

US DEPARTMENT OF ENERGY

under contract DE-AC05-00OR22725 



\section{CONTENTS}

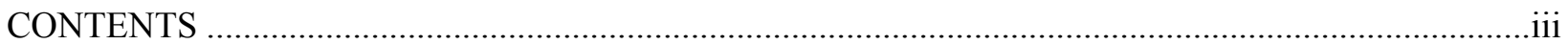

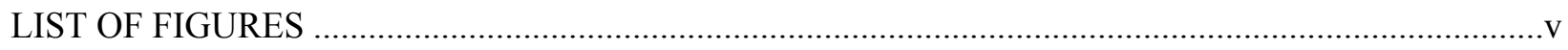

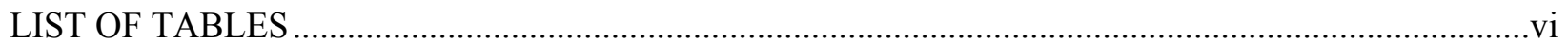

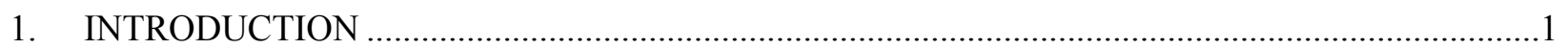

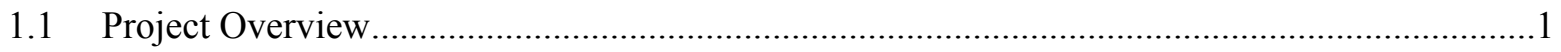

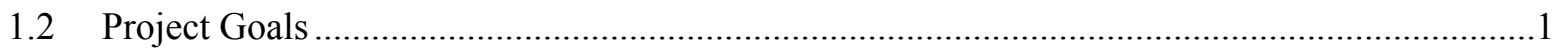

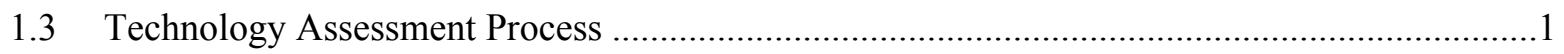

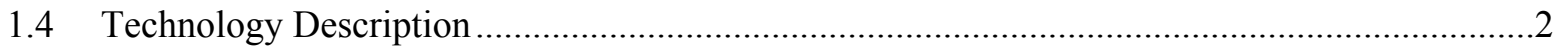

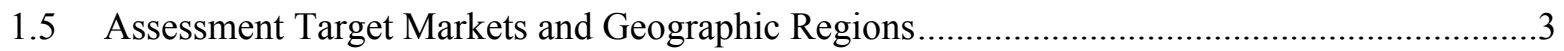

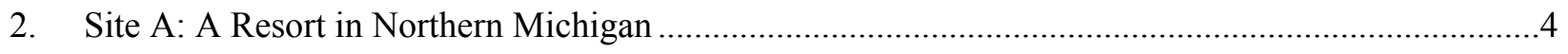

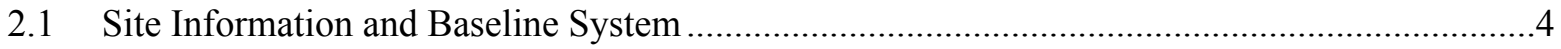

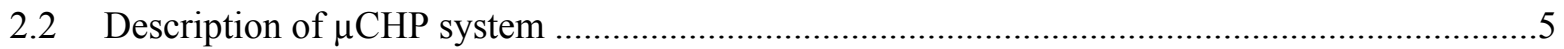

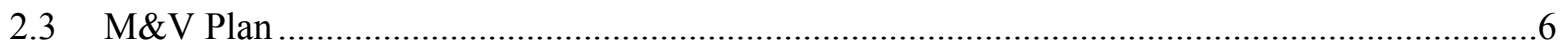

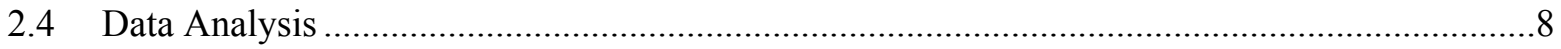

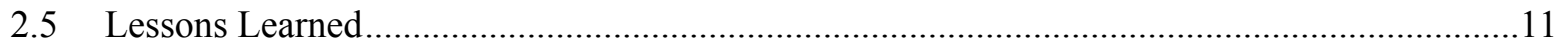

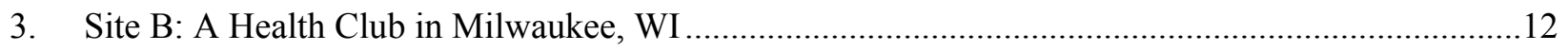

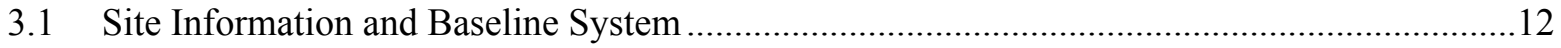

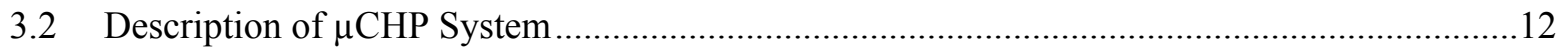

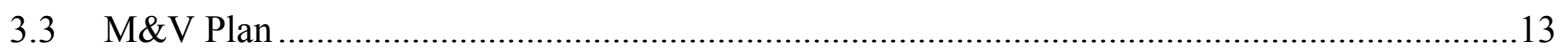

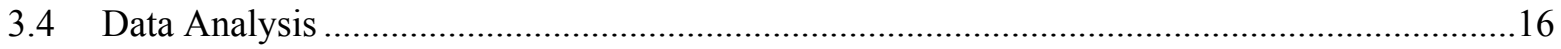

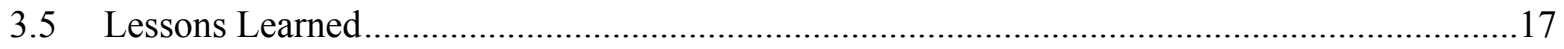

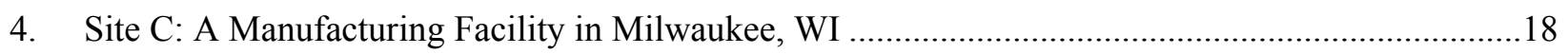

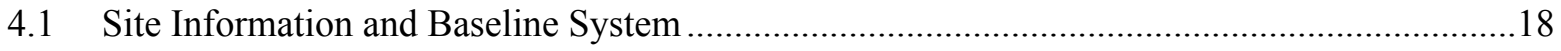

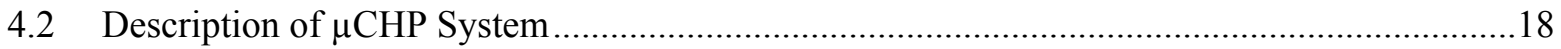

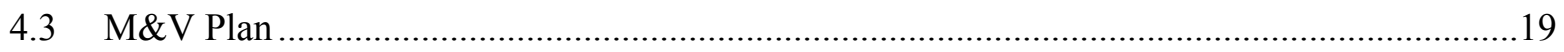

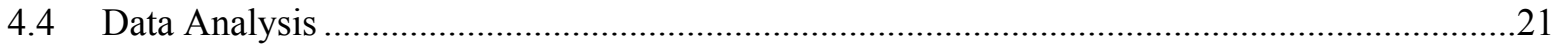

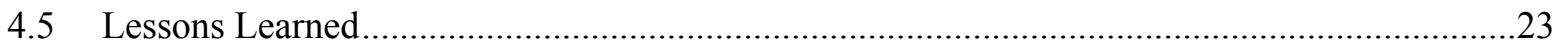

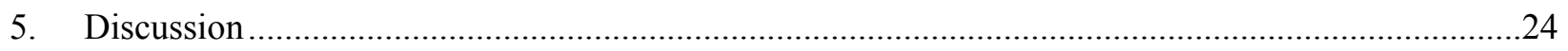





\section{LIST OF FIGURES}

Page

Figure 1: $\mu$ CHP Efficiency vs Conventional System Efficiency, by AO Smith Corporation .......................3

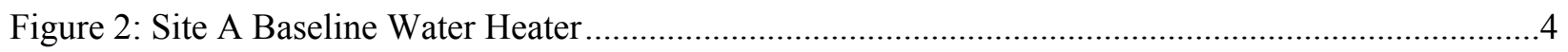

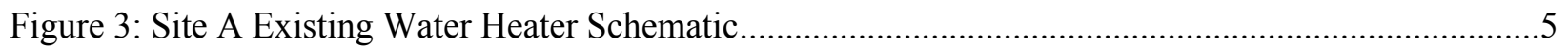

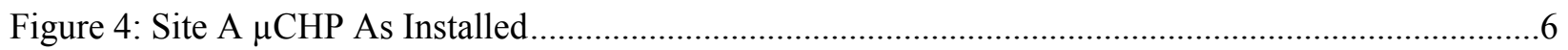

Figure 5: Daily HW load and the baseline boiler system efficiency .....................................................

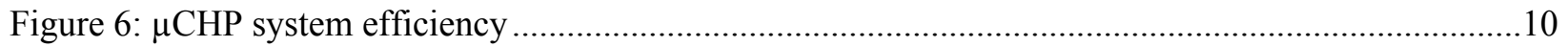

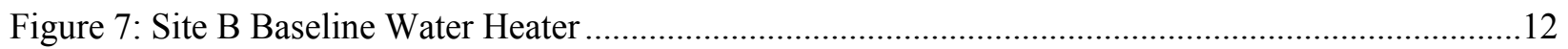

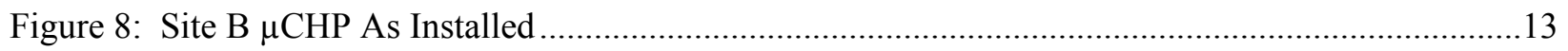

Figure 9: Baseline water heater efficiency as a function of HW load .................................................16

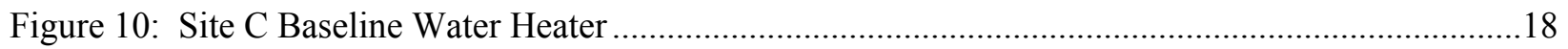

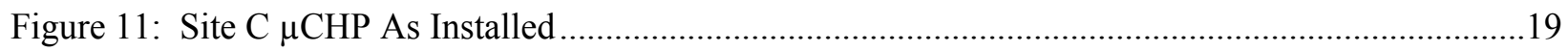

Figure 12: Site C Daily Hot Water Delivered (Baseline) ......................................................................22 


\section{LIST OF TABLES}

Page

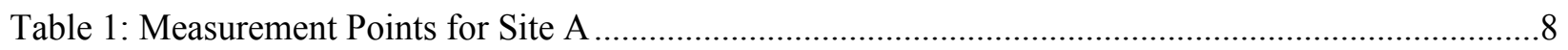

Table 2. Measurement Points for Site B ..................................................................................... 15

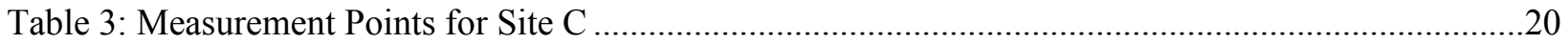





\section{INTRODUCTION}

\subsection{Project Overview}

In 2014 the United States Department of Energy (DOE) Building Technologies Office (BTO) funded a technology assessment of micro Combined Heat and Power ( $\mu \mathrm{CHP}$ ) systems for light commercial applications. The technology assessment was part of the BTO High Impact Technology (HIT) Catalyst program. The HIT Catalyst program supports research and development into technologies that will yield cost-effective, efficient buildings. It is estimated $\mu \mathrm{CHP}$ in US has the potential to save $10.5 \mathrm{GW}$ of primary energy in the commercial building sector.

Oak Ridge National Laboratory was selected to conduct the assessment in collaboration with the $\mu \mathrm{CHP}$ system manufacturer AO Smith Corporation. A total of six demonstration sites were selected based on site visits and interviews with the building owners and operators. Out of six selected sites, three sites were retrofitted with $\mu \mathrm{CHP}$ systems and performance data collected. Three sites went through the initial screening and selection process, but the site owner opted to not continue as part of the research project. This report provides a detailed description of baseline and $\mu \mathrm{CHP}$ system performance, energy savings analysis and lessons learned from the design, installation, and operation of the $\mu \mathrm{CHP}$ systems.

\subsection{Project Goals}

The objectives of this technology assessment were to explore market barriers including perceived lack of value proposition, complexity of system, complex end market interface, and lack of state' regulatory consistency.

The expected outcomes are to provide stakeholders (manufacturers, building owners/national account companies and installers) the information they need in order to make informed decisions regarding deployment of this technology.

Specific goals included:

1) Verifying the value proposition of $<3$ year installed cost payback (independently assess performance to help inform payback evaluation)

2) Identifying and simplifying design, installation and maintenance/service issues

3) Identifying training needs for design, installation and service personnel.

4) Identifying Regulatory Issues - permitting, net metering and tariffs

\subsection{Technology Assessment Process}

The HIT Catalyst assessments follow a similar process that includes:

1. Site Criteria Development

2. Site Recruitment

3. Site Selection

4. General M\&V Plan Development 
5. Site-Specific M\&V Plan Development

6. Install and Commission Data Acquisition

7. Preliminary Data Analysis

8. Develop Technical Report

ORNL prepared a site screening form in collaboration with AO Smith, for AO Smith's potential sites to identify building and operation characteristics. AO Smith then conducted site recruitment, including hosting webinars to present the technology and opportunity to prospective sites. Interested sites were asked to complete a site screening form, after which AO Smith evaluated the information to help select sites that met the occupancy and regional criteria. AO Smith then had a field representative conduct site visits to review the existing installations and further evaluate whether the candidate sites were a good match for a technology retrofit. AO Smith then entered into agreements with the sites selected and arranged for a contractor to retrofit the new $\mu \mathrm{CHP}$ system in parallel with the existing hot water systems.

ORNL developed a general technology measurement and verification $(\mathrm{M} \& \mathrm{~V})$ plan and then customized that for each of the respective sites. ORNL procured the M\&V equipment and worked with AO Smith to get necessary items to the contractor for installation such as gas and water meters. ORNL then commissioned the data acquisition system, collected the baseline and retrofit data, analyzed the data and developed the final report.

\subsection{Technology Description}

The prime mover for the $\mu \mathrm{CHP}$ system is a natural gas-driven Internal Combustion (IC) engine. The engine drives an alternator to generate electricity while waste heat is recovered to deliver hot water for service (domestic) hot water or building (hydronic) heating. The $\mu \mathrm{CHP}$ system can be an alternative to large gas-fired water heaters traditionally installed in facilities with high demand for hot water either for domestic service or for building heating. The system is a thermally led $\mu \mathrm{CHP}$ system, meaning system operation is based on the need for thermal energy (e.g. hot water). When the facility needs hot water the $\mu \mathrm{CHP}$ unit will operate and in turn generate electricity in addition to providing hot water.

Micro combined heat and power systems are generally characterized as those having an electrical output of $50 \mathrm{~kW}$ or less. The $\mu$ CHP system overall has an efficiency of approximately $90 \%$ in converting the supplied natural gas to hot water and electricity. In comparison, for a conventional building installation the overall efficiency would be approximately $60 \%$ due to significant losses in the generation/transmission/distribution process from generation site to the final end-use building. See Figure 1 for system efficiency comparison. 


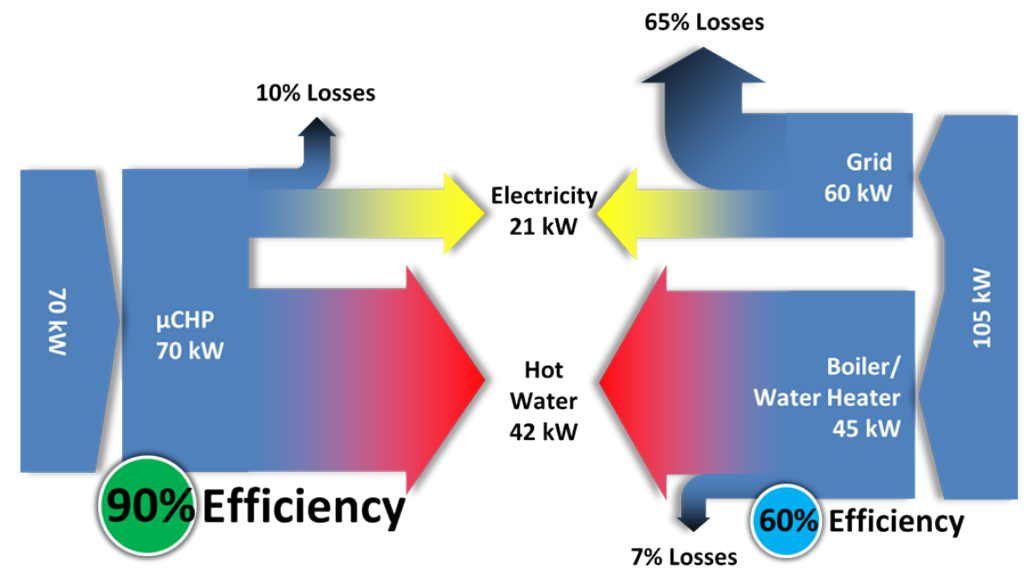

Figure 1: $\mu$ CHP Efficiency vs Conventional System Efficiency, by AO Smith Corporation

\subsection{Assessment Target Markets and Geographic Regions}

The target market for the technology includes light commercial occupancies that have high (e.g. greater than 3000 gallons) daily usage of hot water. Types of occupancies with high domestic hot water usage include full-service restaurants, lodging (under 200 rooms), multi-family housing (75 units and larger), inpatient healthcare, fitness facilities, car washes and laundromats. In addition, light commercial buildings that have hydronic heating are also a target market. A September 2013 analysis by BRG Building Solutions identified a potential $\mu$ CHP market of more than 370,000 buildings in North American as of 2012 with the market growing at approximately $1 \%$ annually.

Three geographic regions were identified as being of most interest for the assessment process. These included the Northeast, Midwest and California. The drivers for selecting these regions included: favorable spark spread, regional inter-connectivity issues, grid reliability issues and California's more rigorous emissions regulations. The spark spread is the difference between the delivered electricity price and the estimated cost to produce power using the $\mu$ CHP system. Areas with high electricity tariffs (combined consumption and demand) are typically areas where spark spread is higher (assuming natural gas is available). Site recruitment efforts were focused on candidate sites in the three target geographic areas. Ultimately the three sites with $\mu \mathrm{CHP}$ installations were from the Midwest (two in Wisconsin and one in Michigan). 


\section{Site A: A Resort in Northern Michigan}

\subsection{Site Information and Baseline System}

The first demonstration site (Site A) is a resort in Northern Michigan. The building is a mixed-use facility including hotel with 500 rooms and four pools, a casino and five restaurants. The total floor area is around 200,000 sq.ft.

The site was selected due to its consistent hot water use, which is optimal for this $\mu$ CHP demonstration project. The existing baseline hot water heater was installed in 1997. The total capacity of the water heater is $961,700 \mathrm{BtuH}$ with a 300 -gallon storage tank. Figure 2 shows the existing baseline DHW system floorplan and Figure 3 shows the system schematic. (See Figure 2 and Figure 3). The hot water delivery temperature has been set to $160 \mathrm{~F}$.

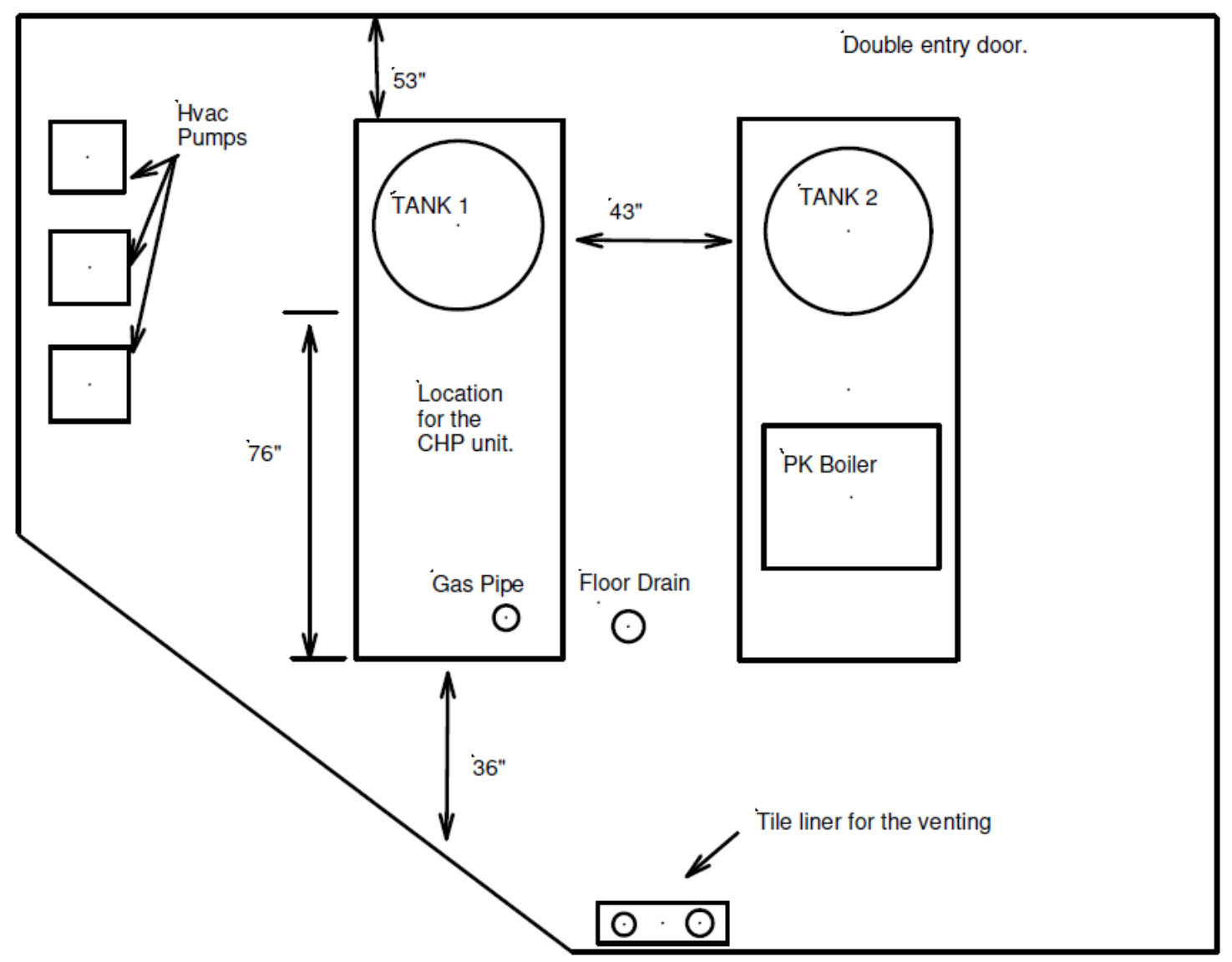

Figure 2: Site A Baseline Water Heater 


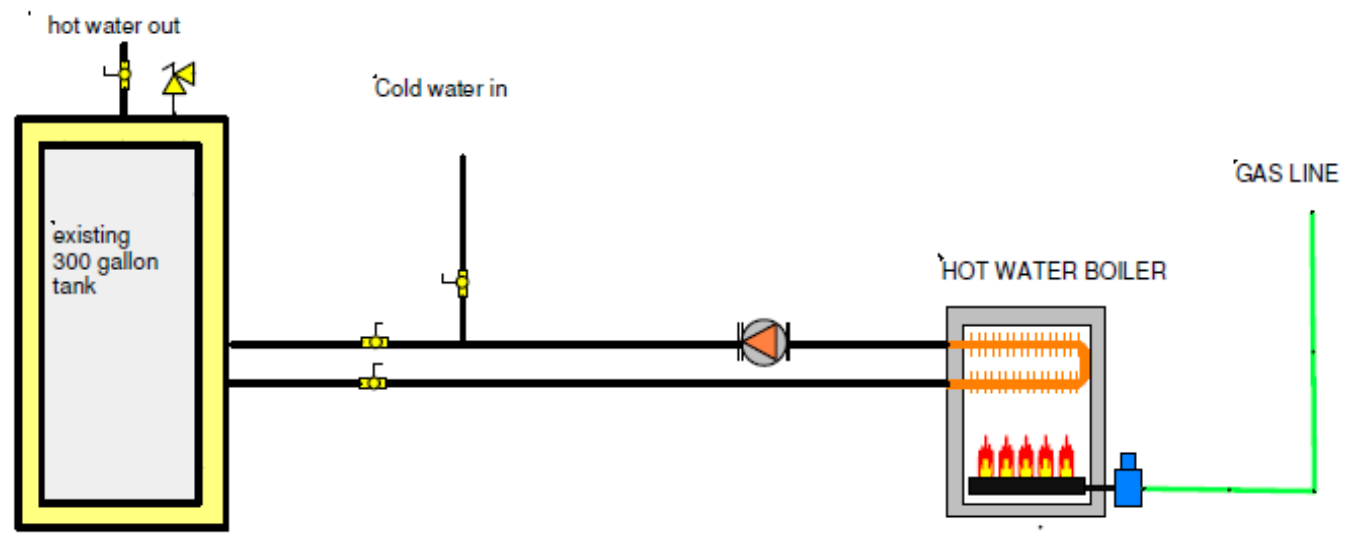

Figure 3: Site A Existing Water Heater Schematic

\subsection{Description of $\mu \mathrm{CHP}$ system}

Figure 4 shows the installed $\mu$ CHP system at the site. The system is a natural gas fired internal combustion engine and control by engine supplier $\mathrm{B}$, and the total capacity of this system is about $25 \mathrm{~kW}_{\text {elec }}$, and $54.9 \mathrm{~kW}_{\text {thermal }}$. The $\mu \mathrm{CHP}$ engine and heat exchanger (HX) were added to the existing baseline system, so that the baseline system can also provide auxiliary hot water when the $\mu \mathrm{CHP}$ cannot provide enough HW to the building. The system includes two new storage tanks connected to the $\mu \mathrm{CHP}$ engine and HX, in addition to the existing 300-gallon storage. The $\mu \mathrm{CHP}$ is controlled to meet $\mathrm{HW}$ demand. 


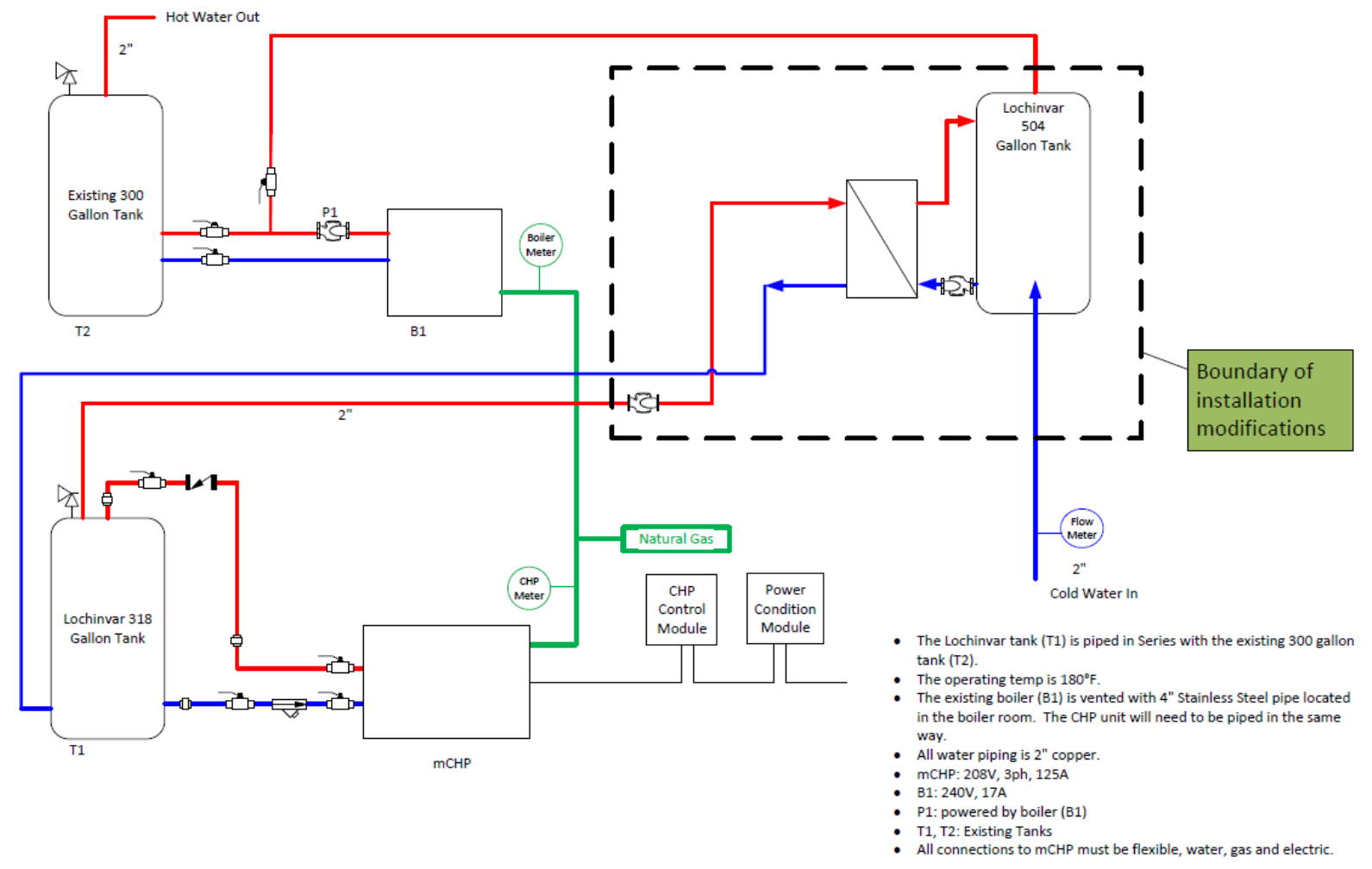

Figure 4: Site A $\mu$ CHP As Installed

\subsection{M\&V Plan}

The measurement and verification plan was developed based on the Option B, Retrofit Isolation with All Parameter Measurement \& Option C, Whole Facility Option (IPMVP Volume I EVO 10000 - 1:2012). In this option, the parameters to measure are 1) natural gas and electricity consumption of existing baseline water heater(s) and new $\mu \mathrm{CHP}$ unit, 2) electricity generation from new $\mu \mathrm{CHP}$ unit, 3) heat output of existing water heater and new $\mu \mathrm{CHP}$ unit. The heat output was estimated base on the inlet and outlet water temperature and total flow measured at water outlet from existing water heater and new $\mu \mathrm{CHP}$ unit. Table 1 shows the measurement points.

The intent of baseline and $\mu \mathrm{CHP}$ performance $\mathrm{M} \& \mathrm{~V}$ is to

- To monitor and understand the baseline and Post-Installation operation and energy consumption of the existing water heater and capture any variations due to internal or external factors.

- To measure electricity and natural gas consumption of the baseline water heater(s) and the new $\mu \mathrm{CHP}$ unit

- To measure electricity generations from the new $\mu \mathrm{CHP}$ unit.

- To evaluate the hot water quality (i.e., temperature rise and flow rate) of the baseline water heater(s) and the new $\mu \mathrm{CHP}$ unit. 
Table 1: Measurement Points for Site A

\begin{tabular}{|l|l|l|l|l|}
\hline No. & Type & Data point & Description & Units \\
\hline $\mathbf{1}$ & Temp & THW1 & Hot water out to buildings & F \\
\hline $\mathbf{2}$ & & TCW1 & Return water into boiler & F \\
\hline $\mathbf{3}$ & \multirow{2}{*}{ Water Flow } & FCW1 & Return water flow to boiler & gpm \\
\hline $\mathbf{4}$ & NG Flow Meter & NG1 & Natural gas for existing boilers & Therms \\
\hline $\mathbf{5}$ & & NG2 & Natural gas for $\mu$ CHP & Therms \\
\hline $\mathbf{6}$ & \multirow{2}{*}{ Power } & Aux1 & Power for Pump & W \\
\hline $\mathbf{7}$ & & Aux2 & Aux power for $\mu$ CHP & W \\
\hline $\mathbf{8}$ & & $\mu$ CHP_Power & Power generated from $\mu$ CHP & W \\
\hline $\mathbf{9}$ & & Aux3 & Any aux for boilers & W \\
\hline
\end{tabular}

\section{Baseline M\&V}

Based on the baseline monitored data, baseline hot water load (MBtu) will be estimated as below:

$$
\mathrm{Q} 1=\mathrm{K} \times \mathrm{FCW} 1 \times(\mathrm{THW} 1-\mathrm{TCW} 1) / 1000
$$

Where:

$\mathrm{Q} 1$ = Baseline hot water load (MBtu) for building

FCW1 = Baseline water flow (gpm)

THW1 $=$ baseline boiler supply hot water temperature $(\mathrm{F})$

TCW1 $=$ baseline boiler feed water temperature (F)

$\mathrm{K}=500$ (conversion constant)

In addition, the baseline system efficiency is calculated as below

Where:

$$
\mathrm{BE} 1=\mathrm{Q} 1 /(\mathrm{NG} 1 / 100)
$$

BE1 = baseline system efficiency (\%)

Baseline energy use $=$ NG1 (therm)

Baseline HW load = Q1 (MBtu)

\section{$\underline{\mu \mathrm{CHP} M \& \mathrm{~V}}$}

In a similar fashion, the post retrofit hot water load will be estimated as below.

Where:

$$
\mathrm{Q} 2=\mathrm{K} \times \text { FCW2 } \times(\text { THW2-TCW2)/1000 }
$$

$\mathrm{Q} 2=(\mu \mathrm{CHP}+$ baseline boiler) hot water load (MBtu) for building

$\mathrm{K}=500$ (conversion constant)

FCW2 $=$ System water flow $(\mathrm{gpm})$

THW2 $=$ Supply hot water temperature $(\mathrm{F})$ 
$\mathrm{TCW} 2=\mu \mathrm{CHP}$ feed water temperature $(\mathrm{F})$

\section{$\underline{\text { Savings Calculation }}$}

Once baseline and post retrofit hot water load and baseline system efficiency are calculated, the energy and cost savings calculation will be calculated as below.

NG Savings $=100 \times(\mathrm{Q} 2 / \mathrm{BE} 1)-\left(\mathrm{NG} 1_{\mu \mathrm{CHP}}+\mathrm{NG} 2_{\mu \mathrm{CHP}}\right)$

Where, $\mathrm{Q} 2=(\mu \mathrm{CHP}+$ baseline boiler $)$ hot water load (MBtu) for building.

$\mathrm{BE} 1$ = baseline system efficiency $(\%)$

$\mathrm{NG}_{\mu \mathrm{CHP}}=\mathrm{NG}$ use for $\mu \mathrm{CHP}($ therm)

$\mathrm{NG} 2_{\mu \mathrm{CHP}}=\mathrm{NG}$ use for existing boilers as back up during $\mu \mathrm{CHP}$ operation (therm)

Elec. Savings $=A u x 1_{\text {baseline }}-\operatorname{Aux} 1_{\mu \mathrm{CHP}}-\mathrm{Aux} 2+\mu \mathrm{CHP}$ Power

Where,

Aux $1_{\text {Baseline }}=$ Aux elec. use for boiler pump for baseline operation $(\mathrm{kWh})$

Aux $1_{\mu \mathrm{CHP}}=$ Aux elec. use for boiler pump for $\mu$ CHP operation $(\mathrm{kWh})$

Aux2 = Aux elec. use for $\mu$ CHP operation $(\mathrm{kWh})$

$\mu \mathrm{CHP} \_$Power $=$Electricity generated by $\mu \mathrm{CHP}$ operation $(\mathrm{kWh})$

Total Energy Cost Savings ${ }^{1}=$ Elec. Savings $(\mathrm{kWh})$ x Elec.rate $(\$ / \mathrm{kWh})+$ NG. Savings (therms $) \times$ NG rate $(\$ /$ therm $)$

\subsection{Data Analysis}

\subsubsection{Baseline Analysis}

Baseline data has been monitored since 7/1/2017 through 8/7/2017. The baseline system efficiency was calculated, and the efficiency varied from $\sim 30 \%$ to $55 \%$ per operational condition (i.e., daily hot water use). Figure 5 shows the relationship between the daily HW load and the boiler efficiency, which shows the logarithmic regression model.

$\mathrm{Y}=0.0974 \ln (\mathrm{x})-0.2845$

Where,

$\mathrm{Y}=$ Boiler efficiency $(\%)$

$\mathrm{X}=$ Daily HW use (MBtu)

\footnotetext{
${ }^{1}$ Only energy cost savings were calculated, and no $\mu \mathrm{CHP}$ investment cost was considered in this analysis.
} 


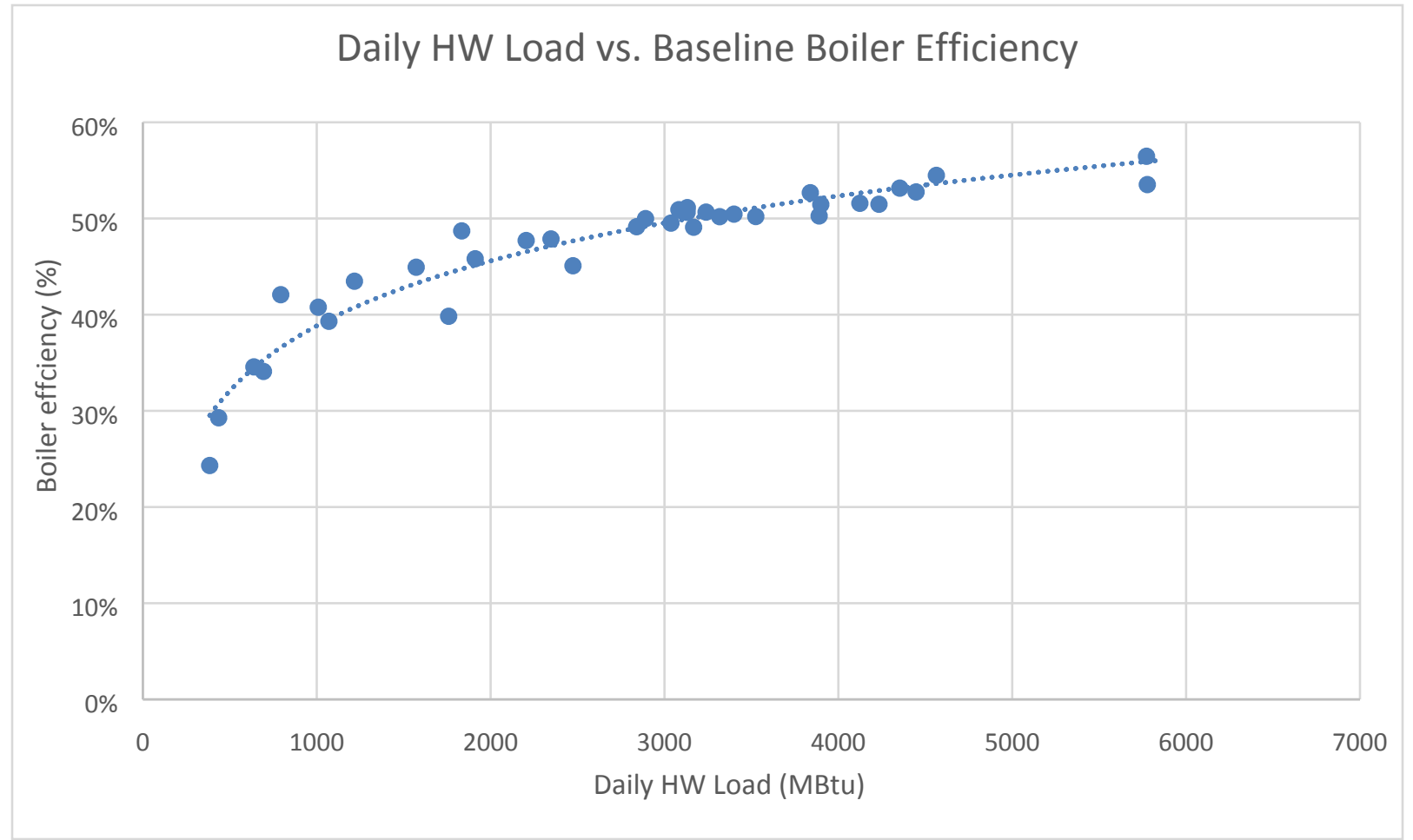

Figure 5: Daily HW load and the baseline boiler system efficiency

\subsection{2 $\mu$ CHP Operation Analysis}

$\mu$ CHP system was installed and has been operated since 9/1/2017. Only the days with normal operations without any major issue were selected for the analysis. In order to evaluate how well the $\mu$ CHP system has been performed, several evaluation metrics were considered including thermal efficiency, effective electric efficiency, and total system efficiency as well as total utility cost savings compare to normalized baseline energy use.

The electric efficiency for this system was calculated, and it varies from $15 \%$ to $20 \%$, while the thermal efficiency varies $35 \%$ to $67 \%$.

Total system efficiency of this $\mu \mathrm{CHP}$ system varies $53 \%$ to $83 \%$. The lower system efficiency was shown when the HW load was relatively lower (Figure 6). While efficiencies vary for $\mu$ CHP installations based on site-specific parameters, a properly designed $\mu$ CHP system will typically operate with an overall efficiency of $65-85 \%{ }^{2}$, which is consistent with the system efficiency of this site.

2 (https://www.energy.gov/sites/prod/files/2017/12/f46/CHP\%20Overview-120817 compliant_0.pdf) 


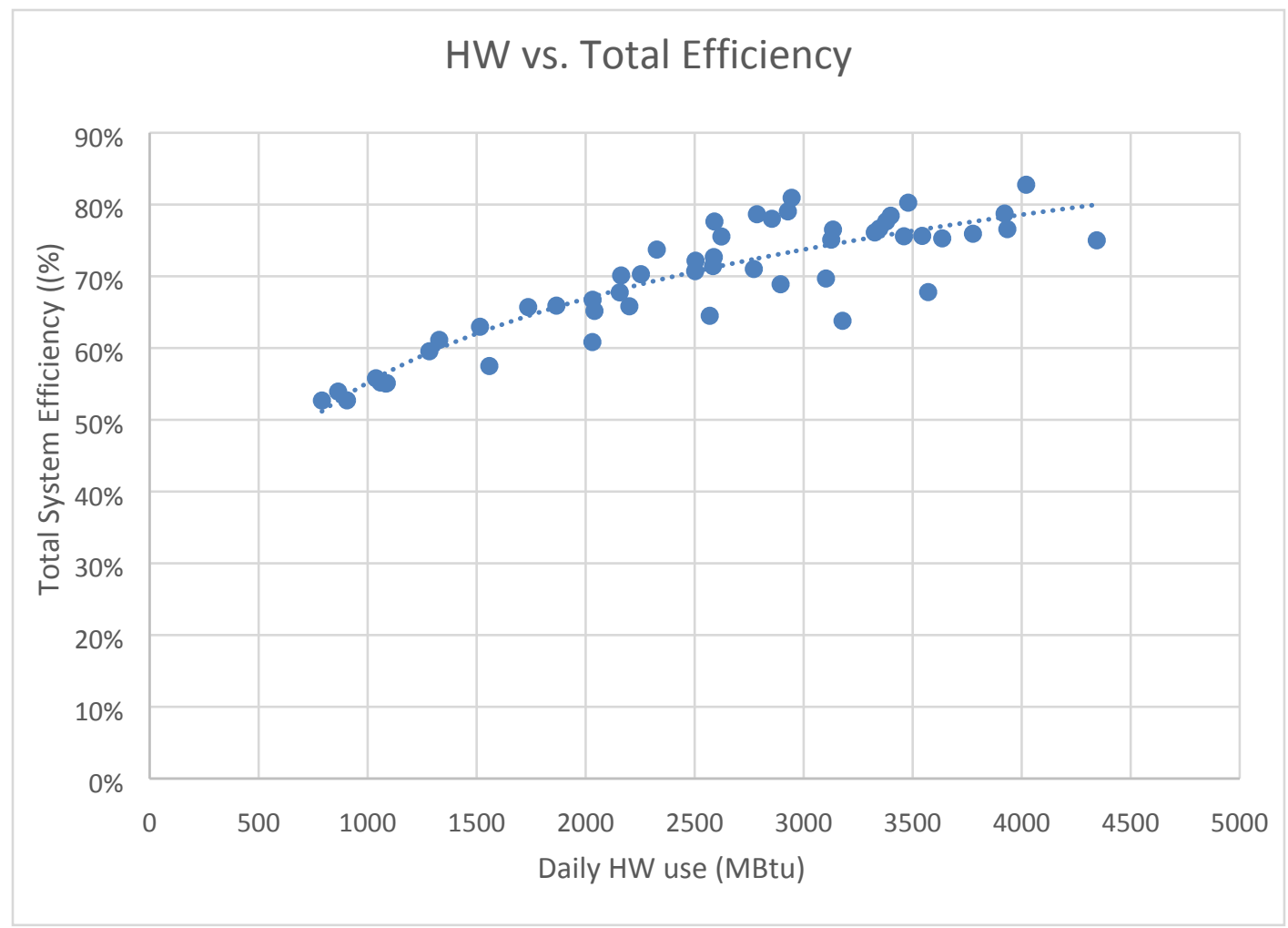

Figure 6: $\mu$ CHP system efficiency

\subsubsection{Cost Savings Analysis}

In order to calculate the energy cost savings, average annual utility rates were assumed. According to EIA, the average elec. and NG rate for Michigan in 2017 were $\$ 0.1128 / \mathrm{kWh}$ and $\$ 0.702 / \mathrm{ccf}$ (therm), respectively. During the $\mu \mathrm{CHP}$ operations, the $\mu \mathrm{CHP}$ system generated $18,680 \mathrm{kWh}$ of electricity. The total NG use for boiler and $\mu \mathrm{CHP}$ system were 1,073 therm, and 2,486 therm, respectively. Therefore, the total NG use for $\mu \mathrm{CHP}$ system was 3,559 therm.

For the same period, the baseline boiler system would use 3,366 therm of NG, which is slightly lower NG use than the use of $\mu \mathrm{CHP}$ system.

Therefore, the total operational cost savings were $\$ 1,851$, which is about $\$ 38$ savings per day. The daily savings \% varies $47 \%$ to $69 \%$ per daily $\mathrm{HW}$ use.

In addition to the savings calculation, the delivered HW temperature for the $\mu \mathrm{CHP}$ system was evaluated. The HW temperature during $\mu \mathrm{CHP}$ operation was average $161 \mathrm{~F}$ with minimum and maximum temperatures of 160 and 162. This is similar with the delivered temperature of baseline operation case, which indicate the $\mu \mathrm{CHP}$ system has been working properly. 


\subsection{Lessons Learned}

Some site performance issues were noted initially. These were determined to be associated with a system capacity/circulator pump undersizing for the original hot water system. An additional 504-gallon storage tank with a plate and frame heat exchanger was added to increase stored hot water capacity.

Engine supplier made some adjustments to improve select subcomponent performance during the demonstration. This included a power control box.

Some minor disruptions in $\mu \mathrm{CHP}$ system operation or data collection were noted during the assessment period. For example, 1) site staff inadvertently switched off a circulator pump in March 2017, and 2)

twice site staff performing boiler maintenance opened a bypass valve which affected the water circulation path and impacted data collection for the cold-water inlet temperature. 


\section{Site B: A Health Club in Milwaukee, WI}

\subsection{Site Information and Baseline System}

The second site selected for the demonstration is a health club located in Milwaukee, WI. The facility is used for fitness club and gym and would be expected to have high and constant HW use.

The baseline system shown in Figure 7 has two water heaters to provide $133 \mathrm{~F}$ to $150 \mathrm{~F}$ HW to the building.

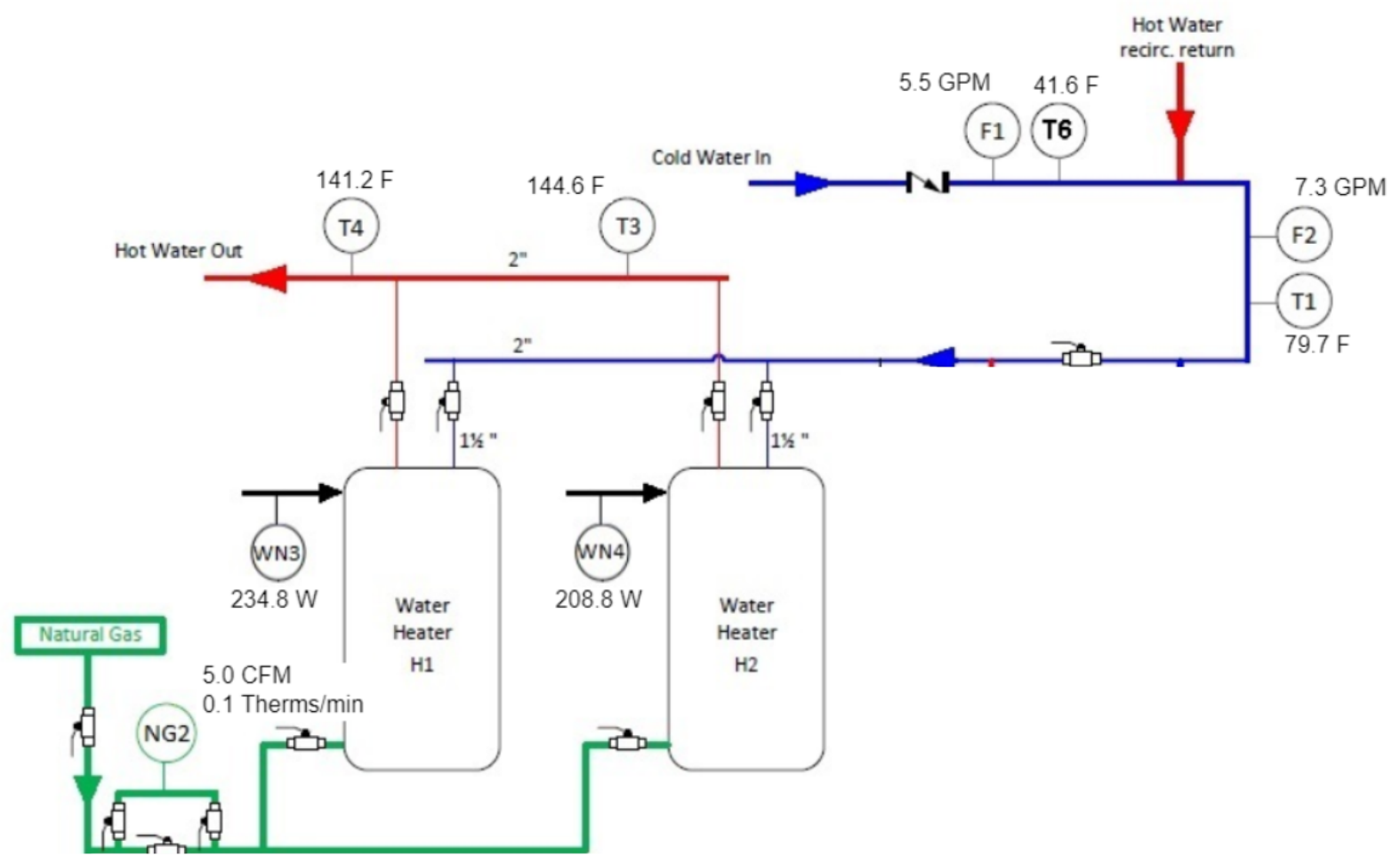

Figure 7: Site B Baseline Water Heater

\subsection{Description of $\mu \mathrm{CHP}$ System}

Figure 8 shows the installed $\mu$ CHP system at the site. The system is a natural gas fired internal combustion engine and control by engine supplier $\mathrm{B}$, and the total capacity of this system is about $21 \mathrm{~kW}_{\text {elec }}$ and $42 \mathrm{~kW}_{\text {thermal }}$. The $\mu \mathrm{CHP}$ engine and $\mu \mathrm{CHP}$ storage tank are added to the existing baseline system, so that the baseline system can also provide auxiliary hot water when the $\mu$ CHP cannot provide enough HW to the building. 


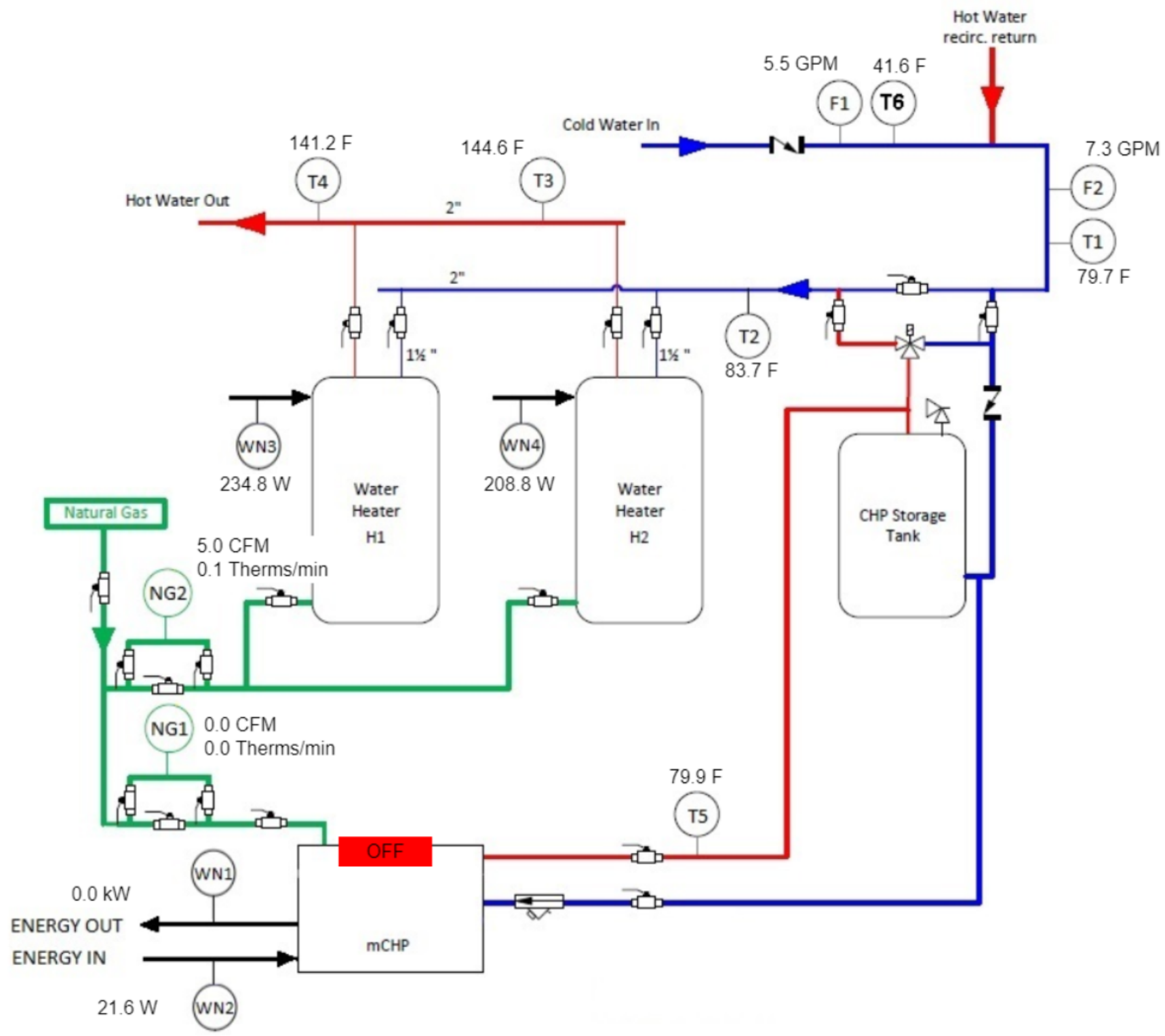

Figure 8: Site B $\mu$ CHP As Installed

\subsection{M\&V Plan}

The measurement and verification plan was developed based on the Option B, Retrofit Isolation with All Parameter Measurement \& Option C, Whole Facility Option (IPMVP Volume I EVO 10000 - 1:2012). In this option, the parameters to measure are 1) natural gas and electricity consumption of existing baseline water heater(s) and new $\mu \mathrm{CHP}$ unit, 2) electricity generation from new $\mu \mathrm{CHP}$ unit, 3 ) heat output of existing water heater and new $\mu \mathrm{CHP}$ unit. The heat output was estimated base on the inlet and outlet water temperature and total flow measured at water outlet from existing water heater and new $\mu \mathrm{CHP}$ unit. Table 1 shows the measurement points. 
The intent of baseline and $\mu \mathrm{CHP}$ performance $\mathrm{M} \& \mathrm{~V}$ is to

- To monitor and understand the baseline and Post-Installation operation and energy consumption of the existing water heater and capture any variations due to internal or external factors.

- To measure electricity and natural gas consumption of the baseline water heater(s) and the new $\mu \mathrm{CHP}$ unit

- To measure electricity generations from the new $\mu \mathrm{CHP}$ unit.

- To evaluate the hot water quality (i.e., temperature rise and flow rate) of the baseline water heater(s) and the new $\mu$ CHP unit.

Table 2. Measurement Points for Site B

\begin{tabular}{|l|l|l|l|l|}
\hline No. & Type & $\begin{array}{l}\text { Data } \\
\text { point }\end{array}$ & Description & Units \\
\hline $\mathbf{1}$ & \multirow{2}{*}{ Temperature } & T1 & Feed water Temp to $\mu$ CHP storage tank & F \\
\hline \multirow{2}{*}{} & & T2 & Water temperature after $\mu$ CHP storage tank & F \\
\hline $\mathbf{3}$ & & T3 & Water temperature after the first water heater & F \\
\hline $\mathbf{4}$ & & T4 & Water temperature after the second water heater & F \\
\hline $\mathbf{5}$ & & T5 & $\begin{array}{l}\text { Baseline water heater supply hot water } \\
\text { temperature }\end{array}$ & F \\
\hline $\mathbf{6}$ & \multirow{2}{*}{ Water Flow } & F1 & Water flow for cold water in & gpm \\
\hline $\mathbf{7}$ & & F2 & Water flow for main hot water line & gpm \\
\hline $\mathbf{8}$ & NG Flow Meter & NG1 & Natural gas for $\mu$ CHP & Therms \\
\hline $\mathbf{9}$ & & NG2 & Natural gas for water heaters & Therms \\
\hline $\mathbf{1 0}$ & Power & WN1 & Power generation from $\mu$ CHP & W \\
\hline $\mathbf{1 1}$ & & WN2 & Aux power for $\mu$ CHP & W \\
\hline
\end{tabular}

\section{$\underline{\text { Baseline M\&V }}$}

The baseline hot water load (MBtu) will be estimated as below:

$$
\mathrm{Q} 1=\mathrm{K} \times \mathrm{F} 2 \times(\mathrm{T} 4-\mathrm{T} 1) / 1000
$$

Where:

$\mathrm{Q} 1=$ Baseline hot water load $(\mathrm{MBtu})$ for building

$\mathrm{F} 2$ = Baseline water flow (gpm)

$\mathrm{T} 4=$ baseline water heater supply hot water temperature $(\mathrm{F})$

$\mathrm{T} 1=$ baseline feed water temperature $(\mathrm{F})$

$\mathrm{K}=500$ (conversion constant)

In addition, the baseline system efficiency is calculated as below

$$
\mathrm{BE} 1=\mathrm{Q} 1 / \mathrm{NG} 2
$$

Where:

$\mathrm{BE} 1$ = baseline system efficiency $(\%)$ 
Baseline energy use $=$ NG2 (therm)

Baseline HW load = Q1 (MBtu)

\section{$\mu$ CHP M\&V}

In a similar fashion, the post retrofit hot water load from $\mu \mathrm{CHP}$ and the baseline boiler will be estimated as below. Unlike Site A, this site has a separate measurement for $\mu \mathrm{CHP}$ hot water load (MBtu) and Water heater hot water load (MBtu) during $\mu \mathrm{CHP}$ Operation, so each hot water load is calculated individually, and combined to have total hot water load.

$\mathrm{Q} 2=\mathrm{K} \times \mathrm{F} 2 \times(\mathrm{T} 2-\mathrm{T} 1) / 1000$

Where:

Q2 $=\mu$ CHP hot water load (MBtu) for building

$\mathrm{K}=500$ (conversion constant)

$\mathrm{F} 2=$ System water flow $(\mathrm{gpm})$

T2 $=$ HWT after $\mu$ CHP storage tank/before water heaters $(\mathrm{F})$

$\mathrm{T} 1=\mu \mathrm{CHP}$ storage tank feed water temperature $(\mathrm{F})$

$\mathrm{Q} 3=\mathrm{K} \times \mathrm{F} 2 \times(\mathrm{T} 4-\mathrm{T} 2) / 1000$

Where:

Q3 = Water heater hot water load (MBtu) during $\mu$ CHP Operation

$\mathrm{K}=500$ (conversion constant)

F2 = System water flow (gpm)

$\mathrm{T} 4=$ Supply hot water temperature $(\mathrm{F})$

$\mathrm{T} 2=$ HWT after $\mu$ CHP storage tank/before water heaters $(\mathrm{F})$

\section{$\underline{\text { Savings Calculation }}$}

Once baseline and post retrofit hot water load and baseline system efficiency are calculated, the energy and cost savings calculation will be calculated as below.

NG Savings $=100 \times((\mathrm{Q} 2+\mathrm{Q} 3) / \mathrm{BE} 1)-(\mathrm{NG} 1+\mathrm{NG} 2)$

Where,

$\mathrm{Q} 2=\mu \mathrm{CHP}$ hot water load (MBtu) for building

Q3 = Water heater hot water load (MBtu) during $\mu$ CHP Operation

$\mathrm{BE} 1=$ baseline water heater efficiency $(\%)$

NG1 $=$ NG use for $\mu$ CHP (therm)

NG2 $=$ NG use for water heaters

Elec. Savings $=\mathrm{WN} 1-\mathrm{WN} 2$

Where,

$\mathrm{WN} 1=$ Power generation from $\mu \mathrm{CHP}(\mathrm{kWh})$

$\mathrm{WN} 2=$ Aux elec. use for $\mu \mathrm{CHP}$ operation $(\mathrm{kWh})$ 
Total Energy Cost Savings $=$ Elec. Savings $(\mathrm{kWh})$ x Elec.rate $(\$ / \mathrm{kWh})+$ NG. Savings (therms) x NG rate $(\$ /$ therm $)$

\subsection{Data Analysis}

\subsubsection{Baseline Analysis}

There was no separate baseline operation period, but the water heater efficiency was calculated based on the HW flow and delta temperature before and after water heater storage tanks as described in M\&V plan. The monitoring period was from 12/22/2018 through 6/17/2019. Only the days with normal operations without any major issue were selected for the analysis. The final number of chosen days for the analysis is 137 days. The calculated efficiency varied from $\sim 5 \%$ to $72 \%$ per operational condition (i.e., daily hot water use). Figure 9 shows the relationship between the water heater HW load and the water heater efficiency. The following equation present the water heater efficiency model based on daily HW load.

$\mathrm{Y}=6 \mathrm{E}-01 \mathrm{X}^{0.6443}$

Where, $\mathrm{Y}=$ Water heater efficiency $(\%)$

$\mathrm{X}=$ Daily HW load (kBtu/day)

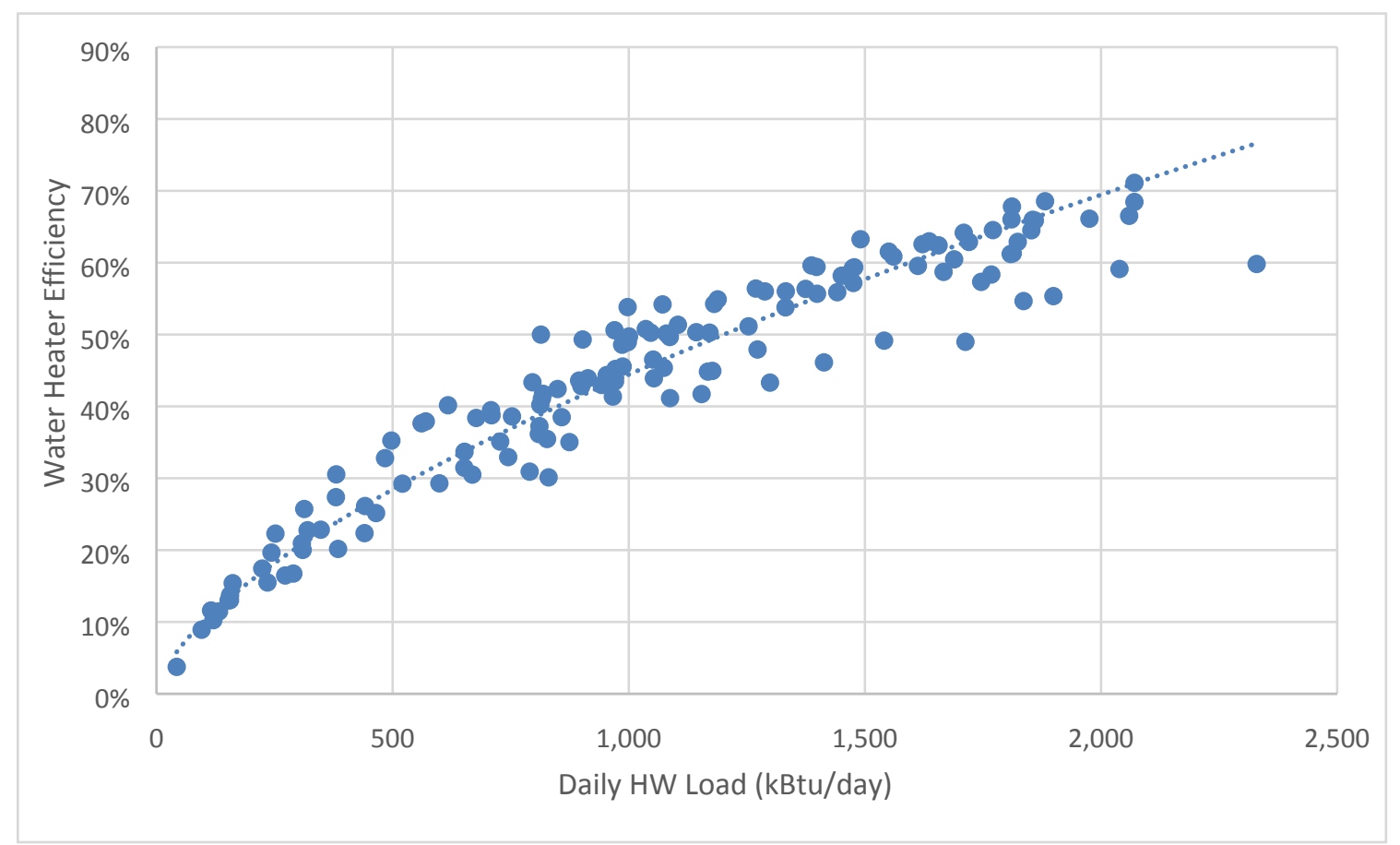

Figure 9: Baseline water heater efficiency as a function of HW load

\subsection{2 $\mu$ CHP Operation Analysis}

$\mu \mathrm{CHP}$ system was installed and has been operated since December 2018. In a similar fashion of Travers site, several evaluation metrics were considered including thermal efficiency, effective electric efficiency, and total system efficiency as well as total utility cost savings compare to normalized baseline energy use. 
The electric efficiency for this system was calculated, and it varies from $32 \%$ to $35 \%$, while the thermal efficiency varies $31 \%$ to $78 \%$. The average total system efficiency was about $90 \%$.

\subsubsection{Cost Savings Analysis}

In order to calculate the energy cost savings, average annual utility rates were assumed. According to EIA, the average elec. and NG rate for Wisconsin in 2018 were $\$ 0.1076 / \mathrm{kWh}$ and $\$ 0.660 / \mathrm{ccf}$, respectively. During the $\mu \mathrm{CHP}$ operations, the $\mu \mathrm{CHP}$ system generated 55,097 kWh of electricity. The total NG use for boiler and $\mu \mathrm{CHP}$ system were 8,505 therm. For the same time period, baseline boiler system would use 5,875 therms of NG. Therefore, total operational cost savings were $\$ 4,388$, which is about $\$ 32$ savings per day.

\subsection{Lessons Learned}

The construction permitting (plans review) process was longer than expected. A review official raised concerns about the possibility of cross-contamination of a potable water source if there were a failure in the heat exchanger. Ultimately the official required that the system's ethylene glycol be replaced with propylene glycol before a construction permit would be issued. The engine supplier reevaluated the system performance and replaced a circulating pump on the $\mu \mathrm{CHP}$ unit to account for the different heat transfer characteristics associated with propylene glycol.

During the assessment period, there was a time period when system hot water needs were not being met. Investigation showed that a valve at a commercial extractor (laundry machine) had failed open and created a large, continuous hot water draw that was greater than the design capacity of the system. The valve was repaired, and system hot water flows and temperatures returned to the expected condition. 


\section{Site C: A Manufacturing Facility in Milwaukee, WI}

\subsection{Site Information and Baseline System}

The final site selected for the demonstration is a manufacturing facility at Milwaukee, WI. This is a laboratory building, and unlike the other two sites where the $\mu \mathrm{CHP}$ system are used for domestic (service) hot water use, this facility uses the $\mu \mathrm{CHP}$ system to provide HW to the building HVAC reheat . Figure 10 shows the existing baseline system diagram. Currently, there are two of $2.0 \mathrm{MBtu}$ boilers with $85 \%$ rated efficiency to provide heating hot water to the reheating loop. The hot water delivery temperature was 140F to 190F during December 2018 through March 2019.

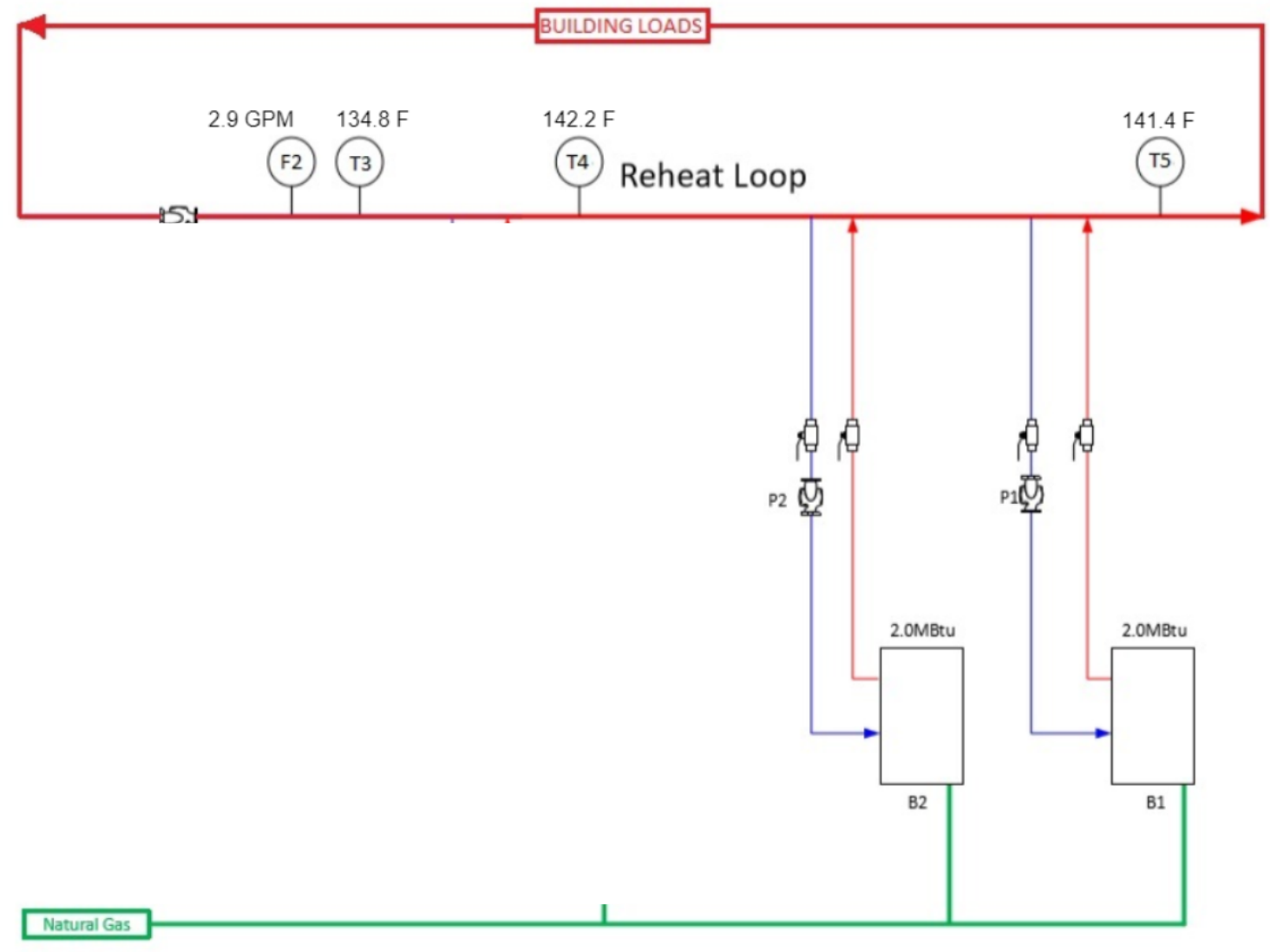

Figure 10: Site C Baseline Water Heater

\subsection{Description of $\mu \mathrm{CHP}$ System}

Figure 11 shows the installed $\mu \mathrm{CHP}$ system at the site. The system is a natural gas fired internal combustion engine and control by engine supplier $\mathrm{B}$, and the total capacity of this system is about $21 \mathrm{~kW}_{\text {elec }}$ and $42 \mathrm{~kW}_{\text {thermal. }}$ The $\mu \mathrm{CHP}$ engine added to the existing baseline system, so that the baseline 
system can also provide auxiliary hot water when the $\mu \mathrm{CHP}$ cannot provide enough hot water to the building.

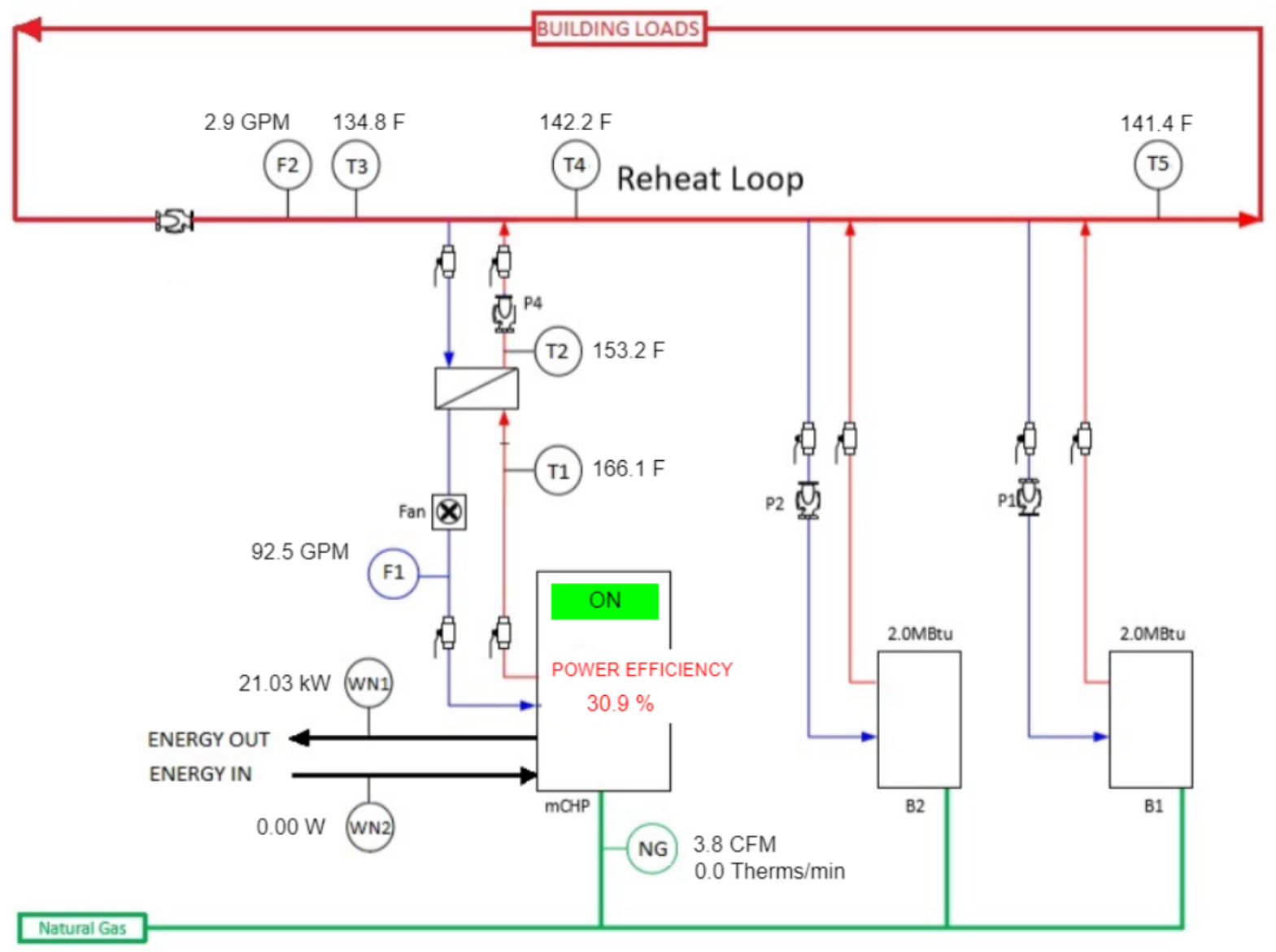

Figure 11: Site C $\mu$ CHP As Installed

\subsection{M\&V Plan}

Table 3 shows the measurement points for Site C.

Table 3: Measurement Points for Site $C$

\begin{tabular}{|l|l|l|l|l|}
\hline No. & Type & $\begin{array}{l}\text { Data } \\
\text { point }\end{array}$ & Description & Units \\
\hline $\mathbf{1}$ & Temperature & T1 & $\begin{array}{l}\mu \mathrm{CHP}: \text { Hot Water Temperature (HWT) from } \\
\mu \mathrm{CHP}\end{array}$ & $\mathrm{F}$ \\
\hline $\mathbf{2}$ & & $\mathrm{T} 2$ & $\mu \mathrm{CHP}:$ HWT to reheat loop from $\mu \mathrm{CHP}$ & $\mathrm{F}$ \\
\hline
\end{tabular}




\begin{tabular}{|c|c|c|c|c|}
\hline & & T3 & Reheat Loop: HWT before $\mu \mathrm{CHP}$ & $\mathrm{F}$ \\
\hline & & $\mathrm{T} 4$ & Reheat Loop: HWT after $\mu$ CHP before Boiler & $\mathrm{F}$ \\
\hline & & T5 & Reheat Loop: HWT after Boiler & $\mathrm{F}$ \\
\hline \multirow[t]{2}{*}{3} & \multirow[t]{2}{*}{ Water Flow } & F1 & Water flow into $\mu \mathrm{CHP}$ & gpm \\
\hline & & $\mathrm{F} 2$ & Water flow reheat loop & gpm \\
\hline 4 & NG Flow Meter & NG & Natural gas for $\mu \mathrm{CHP}$ & Therms \\
\hline 6 & \multirow[t]{2}{*}{ Power } & WN1 & Power generation from $\mu \mathrm{CHP}$ & $\mathrm{W}$ \\
\hline 7 & & WN2 & Aux power for $\mu \mathrm{CHP}$ & $\mathrm{W}$ \\
\hline
\end{tabular}

\section{Baseline M\&V}

Baseline system performance can be analysis as followings.

$\mathrm{Q} 1=\mathrm{K} \times \mathrm{F} 2 \times(\mathrm{T} 5-\mathrm{T} 3) / 1000$

Where:

$\mathrm{Q} 1$ = Baseline hot water load (MBtu) for building

$\mathrm{F} 2$ = Baseline water flow $(\mathrm{gpm})$

$\mathrm{T} 5=$ baseline boiler supply hot water temperature $(\mathrm{F})$

$\mathrm{T} 3=$ baseline boiler feed water temperature $(\mathrm{F})$

$\mathrm{K}=500$ (conversion constant)

$\mathrm{NGB}=\mathrm{Q} 1 / \mathrm{BE} 1$

Where:

BE1 $=$ baseline system efficiency $(\%)-85 \%$ assumed

Baseline energy use $=$ NGB (therm)

Baseline HW load = Q1 (MBtu)

\section{$\mu \mathrm{CHP} M \& \mathrm{~V}$}

In a similar fashion, the post retrofit hot water load from $\mu \mathrm{CHP}$ and the baseline boiler will be estimated as below.

$\mathrm{Q} 2=\mathrm{K} \times \mathrm{F} 2 \times(\mathrm{T} 4-\mathrm{T} 3) / 1000$

Where:

$\mathrm{Q} 2=\mu \mathrm{CHP}$ hot water load (MBtu) for building

$\mathrm{K}=500$ (conversion constant)

$\mathrm{F} 2=$ System water flow $(\mathrm{gpm})$

T4 = Reheat Loop: HWT after $\mu$ CHP before Boiler

$\mathrm{T} 3=\mu$ CHP System feed water temperature $(\mathrm{F})$

$\mathrm{Q} 3=\mathrm{K} \times \mathrm{F} 2 \times(\mathrm{T} 5-\mathrm{T} 4) / 1000$

Where:

Q3 = Boiler hot water load (MBtu) during $\mu$ CHP Operation

$\mathrm{K}=500$ (conversion constant)

$\mathrm{F} 2=$ System water flow (gpm)

$\mathrm{T} 5=$ Supply hot water temperature $(\mathrm{F})$ 
T4 = Reheat Loop: HWT after $\mu$ CHP before Boiler (F)

\section{$\underline{\text { Savings Calculation }}$}

Once baseline and post retrofit hot water load and baseline system efficiency are calculated, the energy and cost savings calculation will be calculated as below.

NG Savings $=100 \times((\mathrm{Q} 2+\mathrm{Q} 3) / \mathrm{BE} 1)-\left(\mathrm{NG}_{\mu \mathrm{CHP}}+100 \times(\mathrm{Q} 3 / \mathrm{BE} 1)\right)$

Where,

$\mathrm{Q} 2=(\mu \mathrm{CHP}+$ baseline boiler $)$ hot water load (MBtu) for building.

$\mathrm{BE} 1$ = baseline system efficiency $(\%)$

$\mathrm{NG}_{\mu \mathrm{CHP}}=\mathrm{NG}$ use for $\mu \mathrm{CHP}$ (therm)

Q3 = Hot water load for existing boilers as back up during $\mu$ CHP operation (MBtu)

Elec. Savings $=$ WN1 - WN2

Where,

$\mathrm{WN} 1=$ Power generation from $\mu \mathrm{CHP}(\mathrm{kWh})$

$\mathrm{WN} 2=$ Aux elec. use for $\mu \mathrm{CHP}$ operation $(\mathrm{kWh})$

Total Energy Cost Savings $=$ Elec. Savings $(\mathrm{kWh}) \times$ Elec.rate $(\$ / \mathrm{kWh})+$ NG. Savings $($ therms $) \times \mathrm{NG}$ rate $(\$ /$ therm $)$

\subsection{Data Analysis}

\subsubsection{Baseline Analysis}

As there was no actual NG use measurement for the baseline boilers, boiler system efficiency of $85 \%$ was assumed based on the manufacturer's data. Figure 12 shows the baseline HW load for 13 days. During these days, the daily HW loads were fluctuated between $782 \mathrm{kBtu}$ to $1,560 \mathrm{kBtu}$ as the daily HW loads varies per building's reheating load. 


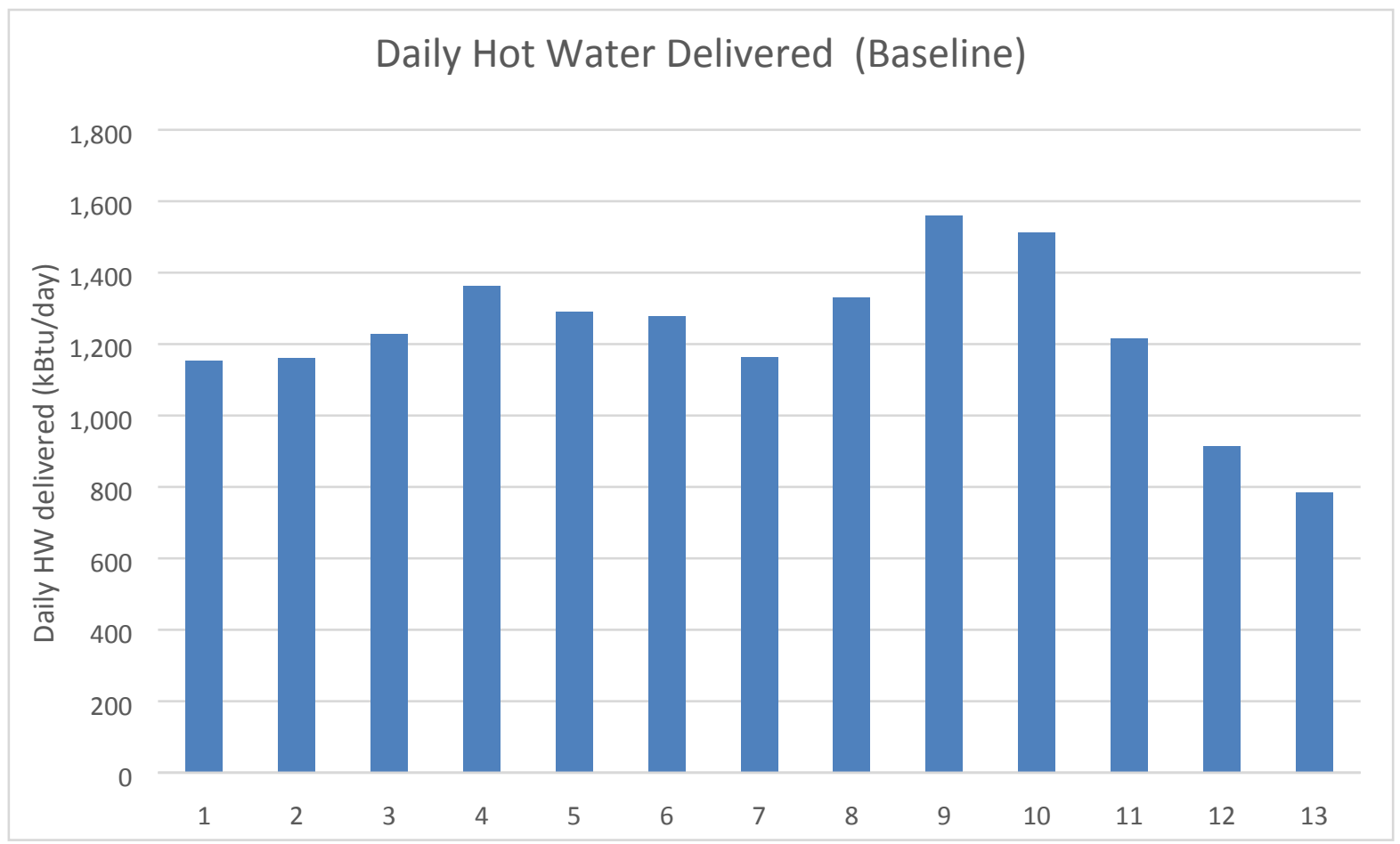

Figure 12: Site C Daily Hot Water Delivered (Baseline)

\subsection{2 $\mu$ CHP Operation Analysis}

For the $\mu \mathrm{CHP}$ operation analysis, 46 days were selected when the $\mu \mathrm{CHP}$ system was operated without any major issue. $\mu$ CHP system was installed and has been operated since December 2018. In a similar fashion of the other two sites, several evaluation metrics were considered including thermal efficiency, electric efficiency, and total system efficiency as well as total utility cost savings compare to normalized baseline energy use.

The electric efficiency for this system was calculated, and it varies from $24 \%$ to $31 \%$, while the thermal efficiency varies $14 \%$ to $39 \%$. The thermal efficiency is relatively low due to the low delta $\mathrm{T}$ compared to Site A. Delta $\mathrm{T}$ for this site is only about 6 to $8 \mathrm{~F}$, while the Site A shows the average Delta $\mathrm{T}$ 60F to 120F. This site uses the $\mu$ CHP system for HVAC reheating (not domestic hot water). With a high hot water return temperature, the operating delta $\mathrm{T}$ is relatively low which in turn reduces the thermal efficiency.

As a result, the total system efficiency varies $44 \%$ to $70 \%$, which is relatively lower than other sites.

\subsubsection{Cost Savings Analysis}

In order to calculate the energy cost savings, average annual utility rate were assumed. According to EIA, the average elec. and NG rate for Wisconsin in 2018 were $\$ 0.1072 / \mathrm{kWh}$ and $\$ 0.660 /$ ccf, respectively. During the $\mu$ CHP operations, the $\mu$ CHP system generated $19,449 \mathrm{kWh}$ of electricity. The total NG use for boiler and $\mu \mathrm{CHP}$ system were 2,237 therm. For the same period, baseline boiler system would use 512 therm of NG, which is about $23 \%$ of $N G$ use for $\mu \mathrm{CHP}$ system. Therefore, the total operational cost savings were $\$ 1,056$, which is about $\$ 23$ savings per day. 


\subsection{Lessons Learned}

One service disruption was noted after system startup. Possible root causes included:

- An unspecified electrical issue

- Colder than normal conditions that required the site to increase the HW temperature from the primary boilers. The incoming (HW return) temperature to the $\mu \mathrm{CHP}$ system needed to be under $150 \mathrm{~F}$, which could not be achieved once the HW loop system temperature was increased. 


\section{Discussion}

The installations ultimately completed for this assessment included two retrofit locations and a laboratory installation. Due to project timing and local codes review issues, a completely new (e.g. greenfield) installation was not available to be evaluated as part of this assessment process. Therefore, it was not possible to directly compare the retrofits versus new installations in terms of effort and issues associated with design, codes review, installation, startup and maintenance.

The three retrofit sites each presented unique site-specific challenges due to existing installation conditions and the codes review process. Some issues initially attributed to the $\mu$ CHP system were in fact caused by the original heating system - including system storage that was somewhat under capacity and a shortage of hot water that was caused by a valve that had failed open. Staff at the commercial building retrofit locations indicated they were very satisfied with the operation of the $\mu$ CHP systems and desired to continue their operation after the assessment had concluded. For site staff, $\mu$ CHP system operation was no more complex than the existing hot water equipment.

Several site installation issues were like those for other forms of Distributed Energy Resources (DER), such as solar photovoltaic (PV) systems, in that electrical system interconnects, safety shutoffs and special electric utility agreements were required. These types of issues are not typical for conventional hot water system equipment installations, therefore installation and training documents that address these issues would be useful for installers.

To better evaluate the impact of the $\mu \mathrm{CHP}$ system on light commercial systems, additional assessments in the remaining target market occupancies (e.g. laundromat, car wash, multi-family housing) would provide additional insight into site-specific installation/operation issues and savings potential. 